\title{
Invasive alien plants in China: diversity and ecological insights
}

\author{
Weber, Ewald ; Sun, Shi-Guo ; Li, Bo
}

\begin{abstract}
China's current invasive alien plant species were analyzed with regard to their floristic status, biological attributes and invasion status elsewhere. Most of the 270 species identified were annuals, followed by perennial herbs. Woody perennials made only about $10 \%$ of the species. The invasives were comprised of 59 families, the largest being Asteraceae, Poaceae, and Brassicaceae. The genera with most invasive species were Amaranthus, Ipomoea, and Solanum. Most of the species originated from the New World, notably from South America. About one-third of the species were serious invaders of natural habitats in countries other than China. The proportion of invasive alien plants in province floras ranged from 0.5 to $3.8 \%$, absolute numbers from nine to 117 species per province. Density of invasive species was correlated positively with native species density at provincial scale. The results demonstrate that in China invasive plants are present throughout the country, with a particularly high species richness in the Southeast. The ecological diversity of invasive plants suggests wide ranging impacts which need to be assessed
\end{abstract}

DOI: https://doi.org/10.1007/s10530-008-9216-3

Posted at the Zurich Open Repository and Archive, University of Zurich ZORA URL: https://doi.org/10.5167/uzh-156496

Journal Article

Published Version

Originally published at:

Weber, Ewald; Sun, Shi-Guo; Li, Bo (2008). Invasive alien plants in China: diversity and ecological insights. Biological Invasions, 10(8):1411-1429.

DOI: https://doi.org/10.1007/s10530-008-9216-3 


\title{
Invasive alien plants in China: diversity and ecological insights
}

\author{
Ewald Weber $\cdot$ Shi-Guo Sun $\cdot$ Bo Li
}

Received: 24 July 2007 / Accepted: 4 January 2008/Published online: 18 January 2008

(C) Springer Science+Business Media B.V. 2008

\begin{abstract}
China's current invasive alien plant species were analyzed with regard to their floristic status, biological attributes and invasion status elsewhere. Most of the 270 species identified were annuals, followed by perennial herbs. Woody perennials made only about $10 \%$ of the species. The invasives were comprised of 59 families, the largest being Asteraceae, Poaceae, and Brassicaceae. The genera with most invasive species were Amaranthus, Ipomoea, and Solanum. Most of the species originated from the New World, notably from South America. About one-third of the species were serious invaders of natural habitats in countries other than China. The proportion of invasive alien plants in province floras ranged from 0.5 to $3.8 \%$, absolute numbers from nine to 117 species per province. Density of invasive species was correlated positively with native species density at provincial scale. The results demonstrate that in China invasive plants are present throughout the country, with a particularly high species richness
\end{abstract}

E. Weber · S.-G. Sun · B. Li ( $\square)$

Coastal Ecosystems Research Station of Yangtze River Estuary, Ministry of Education Key Laboratory for Biodiversity and Ecological Engineering, Institute of Biodiversity Science, Fudan University,

Shanghai 200433, P.R. China

e-mail: bool@fudan.edu.cn

E. Weber $(\bowtie)$

Institute of Environmental Sciences, University of Zurich, 8057 Zurich, Switzerland

e-mail: ewald.weber@uwinst.uzh.ch in the Southeast. The ecological diversity of invasive plants suggests wide ranging impacts which need to be assessed.

Keywords Alien species - Asia .

China $\cdot$ Flora $\cdot$ Invasive alien species

\section{Introduction}

The movement of species by man beyond natural dispersal barriers is a still accelerating process, resulting from global commerce and disturbance of natural ecosystems. Species introductions lead to biological invasions, which can have profound impacts on the regional economy and the ecological integrity of natural communities (Mooney and Hobbs 2000; Pimentel 2002). The number of alien plant species varies considerably among regions (Vitousek et al. 1997), and both socio-economic factors such as human density and degree of urbanization as well as biogeographic factors such as latitude and climate have been identified to correlate with alien species richness (Lonsdale 1999; Rejmánek 2000).

There is also considerable variation in the degree of knowledge of invasive alien species among various regions of the world. Plant invasions and alien floras of North American, Australian and European areas are well documented, whereas many countries of Asia are still understudied (Wu et al. 2004b). 
Compilations of alien weeds or naturalized species for Asian countries and regions other than China are available for Japan (Enomoto 1999), Korea (Koh et al. 2000), the city of Singapore (Corlett 1988, 1992), the city of Chonju, Korea (Zerbe et al. 2004), the Kashmir Himalaya (Khuroo et al. 2007), and Doon Valley, Northwest Himalaya (Negi and Hajra 2007). The most comprehensive study for an east Asian region is probably that for Taiwan (Wu et al. 2004a). Compiling alien floras and analyzing patterns of floristic status, biological attributes, and geographical distribution has proved to be a useful approach to understanding alien species richness in various regions (Rozefelds et al. 1999; Stadler et al. 2000; Pyšek et al. 2004; Pyšek and Richardson 2006), and such datasets represent the necessary baseline information upon which management strategies can be built.

China is the world's third largest country in relation to territory, stretching $5,200 \mathrm{~km}$ from east to west, and spanning $50^{\circ}$ of latitude. Its vast territories cover five climatic zones: tropical, subtropical, warm-temperate, temperate, and coldtemperate (Wang et al. 1997). The complex topography and the wide range of habitats make the country be one of the richest in terms of biological diversity, harbouring approximately 31,000 vascular plant species or one-eighth of the world's total (Flora of China 2007).

China currently undergoes a rapid economic development and increasing international trade, translating into ecological side effects that are of direct significance for the spread of weeds and invasive species, e.g. construction of new roads and railways, increased disturbance, ecological construction, and increased species introductions (Liu et al. 2003; López-Pujol et al. 2006). All these may promote the spread of invasive species and increasingly threat the integrity and diversity of China's unique ecosystems and species. Trade is believed to be a major vector for the introduction of harmful alien species (Convention on Biological Diversity 2002; Levine and D'Antonio 2003), and transport ways allow invasive species to reach remote yet uncolonized areas (Forman and Alexander 1998). The increasing trade between the United States and China (Callaway et al. 2006; Jenkins and Mooney 2006) is likely to onset further invasions, as well as increasing trade with other parts of the world.
The problem of invasive alien species in China has been addressed by a number of authors at both national and regional scales (Guo 1995; Guo and Li 1995; Qiang and Cao 2000; Li et al. 2001; Pan and Tian 2001; Xiang et al. 2002; Xie et al. 2001; Du et al. 2002; Li and Chen 2002; Li and Xie 2002; Chen et al. 2005). The estimated economic losses in China due to invasive alien species amount to US\$ 15 billion annually (Xu et al. 2004). Removal of water hyacinth (Eichhornia crassipes) in Wenzhou city cost 128 million US\$ in 1996 (Ding and Xie 1996). An estimate for the economic loss caused by Mikania micrantha on Neilingding Island ranges from 0.56 to 1.26 million US\$ (Zhong et al. 2004). Data on ecological damages are rather scarce. Zhang et al. (2003) outlined potential ecological damages by the spread of fanwort (Cabomba caroliniana). In parts of Dianchi Lake of Yunnan province, the vigorous growth of water hyacinth outcompeted native hydrophytes, reducing the species number from 16 to 3 (Wu 1993). These few figures indicate the high potential of costs and damages, both ecological and economic, associated with plant invasions in China.

An analysis of regional distribution patterns of invasive alien plant species in China (Liu et al. 2005) showed that species richness among provinces was mainly associated with native species richness and socio-economic factors such as human population density. The currently known invasive alien plant species have, however, not yet been characterized in terms of their ecology and status in other parts of the world. Here, we present such an analysis, based on a literature survey. We address the following basic questions: (1) What is the current number of invasive alien plants in China and what is their status in other places of the world? (2) From where do these species originate? (3) Which growth strategies contribute most to invasive plants? (4) Are biogeographic regions within China different with regard to invasive plants?

\section{Methods}

\section{Data sources}

We consider here only plant species that are alien to China and that are currently invasive. We could not consider the whole array of naturalized alien plant 
species because compiling such a list is not feasible. The term ,invasive species' is used in the sense of McNeely et al. (2001), meaning that they cause damage to species, habitats, or to the economy, and the same definition has been adopted in the sources given below.

The species list was compiled from published literature, e.g. research articles, books and book chapters, and reports (Guo 1995; Guo and Li 1995; Zhang and Han 1997; Ding and Wang 1998; Li 1998; Hsu 1999; Qiang and Cao 2000; Pan and Tian 2001; Xie et al. 2001; Du et al. 2002; Li and Xie 2002; Liu et al. 2002; Xu et al. 2004; Tian 2004; Wu et al. 2004a; Liu et al. 2005; Qiang 2005; Lu et al. 2006; Xu et al. 2006a). A number of species are considered as invasive in some parts of China by the above references, whilst they are native to other parts of the country. These species were not considered in our analyses. Whereas it could not be excluded that plant materials of some of these species were introduced from other parts of Eurasia outside of China, we strictly focused on alien species in our analyses. For a number of species, e.g. Bunias orientalis, Berteroa incana, uncertainty exists with regard to native or alien status in China. The Flora of China checklist database (Flora of China 2007) considers these two species as native, and we therefore excluded them from our analyses. Other species such as Narcissus tazetta represent old introductions (Flora of China 2007) and hence alien to China. Because this species is considered as a noxious weed, we did include it.

\section{Characterization of species}

The species entries were supplemented with data on taxonomic position (family), life form and habitats, origin and distribution within China. Origins were extracted from the sources above and complemented by data on the native range. These were taken from the Germplasm Resources Information Network (USDA 2007).

We indicated the status of the species outside of China (invasive in natural areas elsewhere or not). The latter was granted to a species only if it is a serious invader of natural areas, according to Cronk and Fuller (1995), Daehler (1998), and Weber (2003). The status is called 'invasive elsewhere' hereafter.
We used 'invasive elsewhere' as an indicator for the invasion potential of the respective species. Status as invasive (or weedy) in other countries than the country under consideration is believed to be one of the best predictors of invasibility in plants (Groves et al. 2001).

For 221 species, we could obtain presence-absence data among provinces. For 181 species, we could gather data on habitat types in which the species occur. Habitat type refers to a broad categorization of natural and man-made habitats, e.g. natural forests, lakeshores and river edges, coastal areas, tree plantations and afforestation sites (by native or exotic species), road- and railway sides, grassland and pastures. Information on economic uses of each species was obtained from the above sources and complemented by Wiersema (1999). Economic uses indicate the introduction mode (accidental vs. intentional) and the purpose for introduction in the case of intentionally introduced species. A species was allocated to more than one category if different uses apply to it.

\section{Data analyses}

Analyses comprised of cross-tabulations and correlations. Provinces were taken as spatial units and species density in a province was expressed as $\mathrm{D}=\mathrm{N} / \log (\mathrm{A})$, where $\mathrm{N}$ is the number of species and A the area (Rejmánek and Randall 1994). Correlations were used to analyse relationships between invasive and native species density and richness, respectively, among provinces.

To analyse patterns of similarity among major geographic regions in China, we allocated provinces to four main regions (Fig. 1), e.g. the high plateaus of western China (West), the provinces with subtropical climate not bordering the sea (Central), northeastern provinces (Northeast), and southern provinces bordering the sea (South). Index of similarity (S) of these regions was calculated according to Sørensen (McGarigal 2000) using species richness in these regions as

$\mathrm{S}=(2 \mathrm{C} / \mathrm{A}+\mathrm{B}) \cdot 100$

where $\mathrm{C}$ is the number of common species; $\mathrm{A}$ and $\mathrm{B}$ are the total numbers of species in regions $\mathrm{A}$ and $\mathrm{B}$, respectively. 


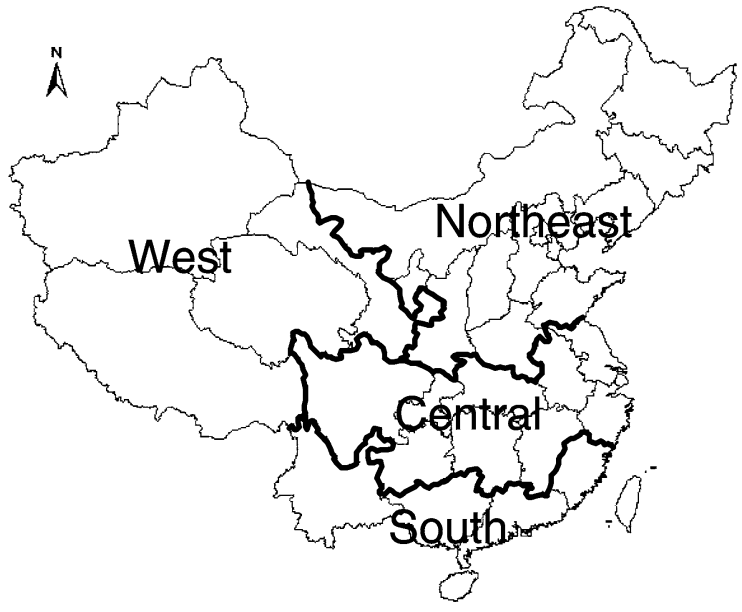

Fig. 1 Regions based on provinces for determining species overlap

\section{Results}

Numbers of invasive plant species and geographic distributions

We identified 270 invasive plant species, corresponding to $0.9 \%$ of the flora of China. They formed a heterogeneous group with regard to taxonomic position and ecological attributes, and are listed in Appendix 1. At least one-third of the species (36.3\%) was invasive elsewhere. The number of invasive species among provinces showed considerable variation (Fig. 2), with the lowest species richness in

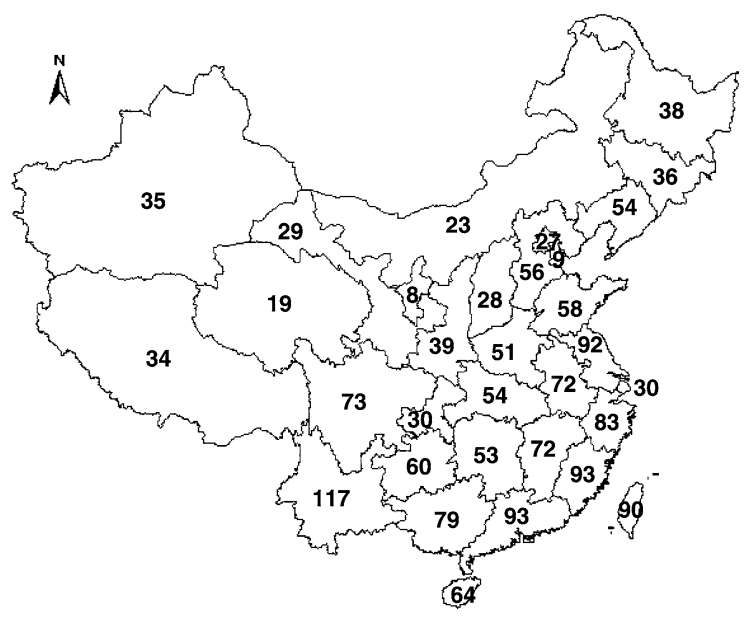

Fig. 2 Invasive alien plant species richness in provinces of China
Tianjin (9 species), and the highest species richness in Yunnan (94), followed by Taiwan (90). The proportion of invasive species among province floras ranged from 3.8\% (Hubei province) to $0.5 \%$ (Qinghai province). A general trend of increasing invasive plant species richness from Northwest to Southeast was apparent (Fig. 2). Invasive plant species richness was correlated significantly with native species richness $\left(R^{2}=0.32, P=0.002\right)$ and with the number of endemic plant species (Fig. 3). Density of invasive plant species was correlated significantly with native species richness (Fig. 3) and with density of endemic plant species $\left(R^{2}=0.21, P=0.017\right)$. Multiple regression analysis showed that the most influential correlates of invasive plant species richness were native plant species richness and human population size (Table 1).

The 10 most widespread species included mostly annuals, growing in disturbed ruderal sites, e.g. Conyza canadensis or Ipomoea purpurea (Appendix 1). A number of species occurred only in one province (56 or $26.9 \%$ of those species for which distributional data were available). Some of the invaders reached high elevations and had a large altitudinal distribution, e.g. Ipomoea purpurea (0-2,800 m asl), Lepidium densiflorum $(0-3,800 \mathrm{~m}$ asl), or Sisymbrium altissimum $(0-2,500 \mathrm{~m}$ asl).

The invasive alien floras of the four biogeographic regions showed distinct similarities to each other (Table 2). Western China was most distinct from the South with regard to invasive alien plant species, whereas central and northeastern provinces had a strong similarity. Western China and the South still shared 48 invasive plant species.

\section{Taxonomic position}

The invasive plant species of China were represented by 59 families and 177 genera (Table 3). About $79.6 \%$ of the species belonged to dictolyedons and $20.4 \%$ to monocotyledons. There were no ferns, fern allies, or gymnosperms that are considered to be invasive. Asteraceae, Poaceae, and Brassicaceae contributed most to the invasive plants in terms of absolute numbers (Fig. 4). Thirty-five families were represented by one species only, and 50 families with five species or less. The three largest families accounted for $40.6 \%$ of all species. 
(a)

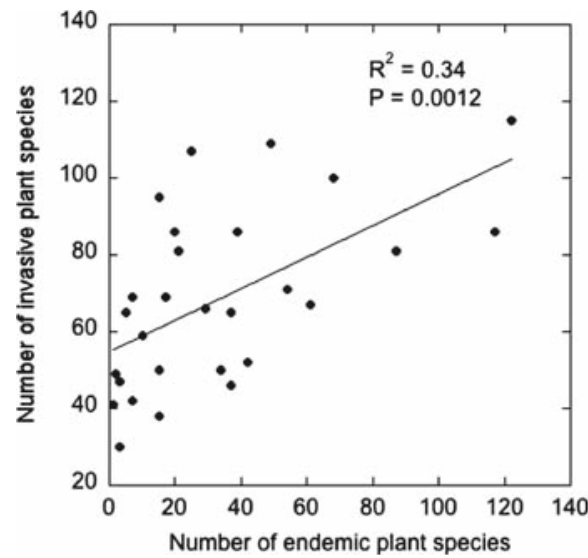

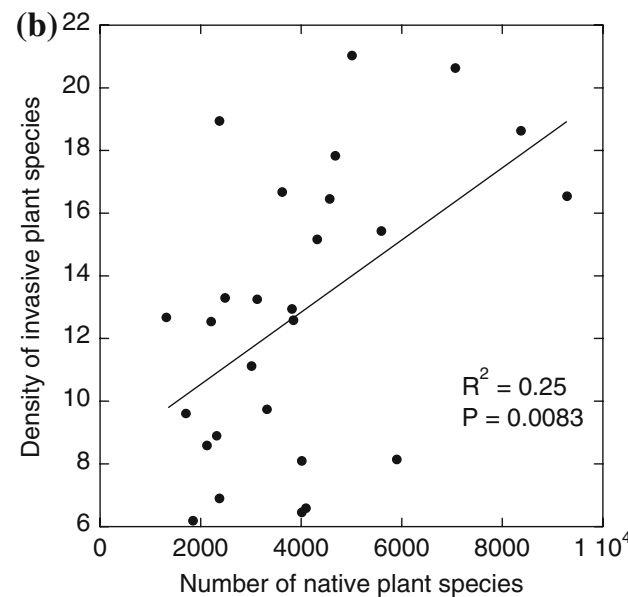

Fig. 3 Relationship between (a) invasive and endemic species richness, and (b) between density of invasive plant species and native species richness in 28 provinces of China

Table 1 Regression analyses showing the influence of geomorphological and socioeconomic factors on invasive plant species richness for 28 provinces in China

\begin{tabular}{lrrrl}
\hline Source & df & Sum of squares & $F$ & $P$ \\
\hline Area & 1 & 429.4 & 2.29 & 0.145 \\
Mid-latitude & 1 & 530.5 & 2.83 & 0.107 \\
Mid-longitude & 1 & 187.6 & 1.00 & 0.328 \\
Number of native plants & 1 & 3841.4 & 20.48 & 0.0002 \\
Population & 1 & 831.8 & 4.43 & 0.047 \\
Error & 22 & 4126.9 & & \\
\hline
\end{tabular}

Table 2 Similarity of the invasive alien floras of four regions of China, e.g. western, southern, northeastern and central China

\begin{tabular}{llllc}
\hline Region & West & South & Northeast & Central \\
\hline West & - & 42.5 & 59.4 & 51.5 \\
South & 188 & - & 48.3 & 67.1 \\
Northeast & 118 & 203 & - & 70.9 \\
Central & 147 & 298 & 155 & - \\
\hline
\end{tabular}

Entries of the upper half are indices of similarity (Sørensen coefficient), of the lower half total numbers of species of the respective pair

The three major genera of invasive species were Amaranthus, Ipomoea, and Solanum (Table 4). Fourty-seven or $26 \%$ of the genera contained only one species. Among the major genera, Ipomoea and Lolium contained most species that are invasive elsewhere. The proportion of species being invasive elsewhere was higher among monocotyledons than
Table 3 Summary statistics for the current invasive alien flora of China

\begin{tabular}{lrrr}
\hline & Dicotyledons & Monocotyledons & Total \\
\hline Family & 47 & 12 & 59 \\
Genus & 140 & 37 & 177 \\
Species & 215 & 55 & 270 \\
Invasive elsewhere & 69 & 29 & 98 \\
Not invasive & 149 & 23 & 173 \\
$\quad$ elsewhere & & & \\
\hline
\end{tabular}

among dicotyledons $\left(\chi^{2}=10.2, P=0.0014\right)$, which is caused by the presence of many grasses in the former.

Geographic origins

Invasive plant species in China originated from all continents (Fig. 5). The fraction of invasive species from the New World totaled to $44.2 \%$, with most species originating from South America. Other important source areas included Europe, North America, and other parts of Asia. Few species of Australian origin were present in China's invasive flora, and also few species whose native range lies solely within Asia. Species that are invasive elsewhere predominated in African and New World species. New World species were overrepresented among dicotyledons compared to Old World species $\left(\chi^{2}=7.48, P=0.006\right)$. 


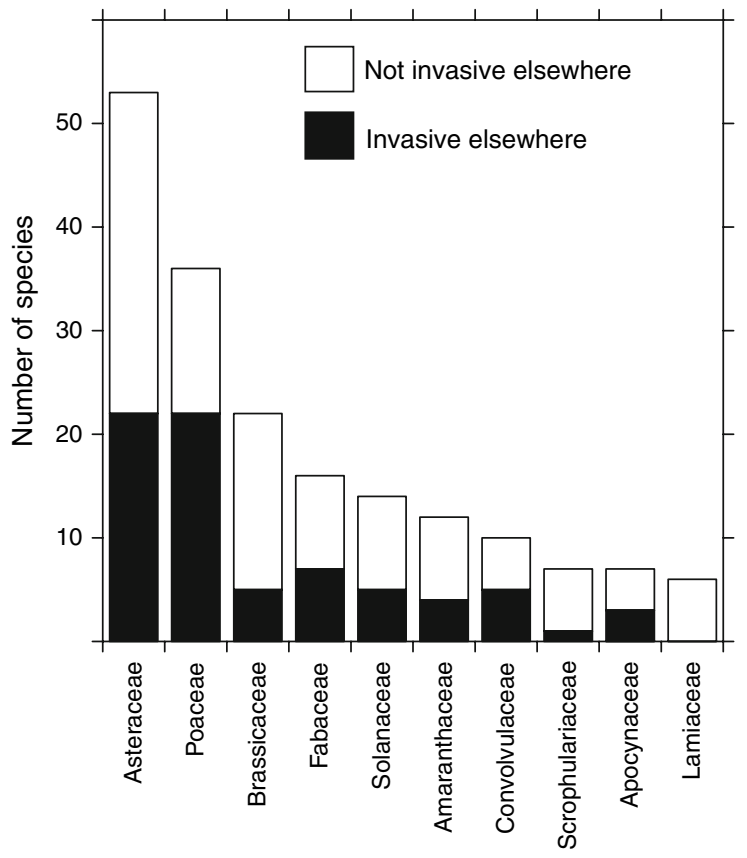

Fig. 4 The 10 major families with their numbers of invasive alien species of the Chinese flora

Table 4 Invasive alien species richness of the ten major genera of invasive plants in China

\begin{tabular}{llll}
\hline Genus & $\begin{array}{l}\text { Invasive } \\
\text { elsewhere }\end{array}$ & $\begin{array}{l}\text { Not invasive } \\
\text { elsewhere }\end{array}$ & Total \\
\hline Amaranthus & 2 & 7 & 9 \\
Ipomoea & 5 & 3 & 8 \\
Solanum & 2 & 5 & 7 \\
Veronica & 0 & 5 & 5 \\
Brassica & 1 & 3 & 4 \\
Euphorbia & 0 & 4 & 4 \\
Lepidium & 0 & 4 & 4 \\
Lolium & 2 & 2 & 4 \\
Ranunculus & 0 & 4 & 4 \\
Trifolium & 1 & 3 & 4 \\
\hline
\end{tabular}

Life forms and habitats

The life form distribution was characterized by a prevalence of annuals and perennial herbs among the invasive plants (Table 5). The majority of climbers were vines of the genus Ipomoea, originating from the New World. Species being invasive elsewhere predominated among succulents and climbers. Woody perennials made only $9.6 \%$ of all invasive

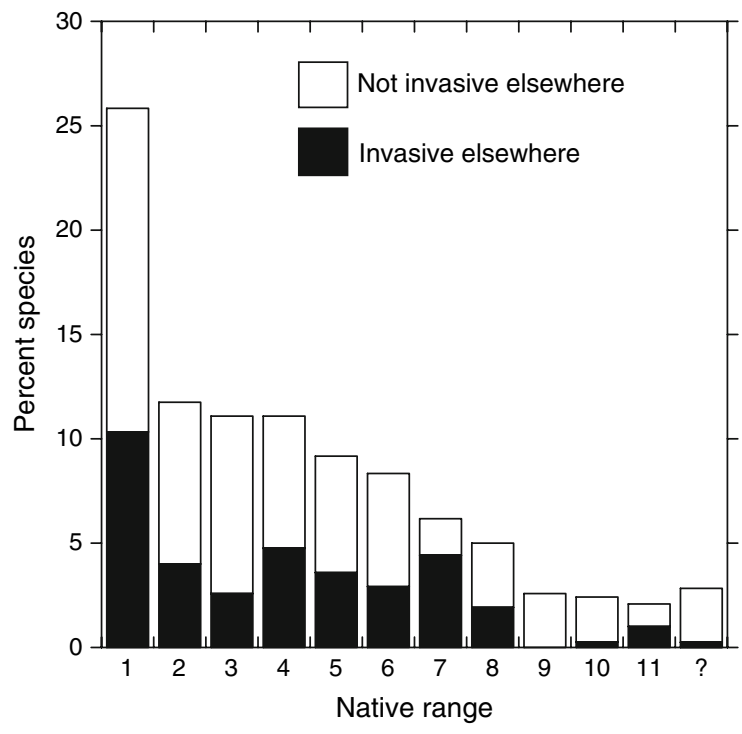

Fig. 5 The native ranges of invasive plant species of China $(N=270)$. Each species was allocated to one category only. $1=$ South America, 2 = Africa, Eurasia, 3 = North America, $4=$ North and South America, $5=$ Europe, $6=$ Eurasia, $7=$ Africa, $8=$ Central America, $9=$ Asia, $10=$ Australia, $11=$ cosmopolitan, ? = unknown

Table 5 Distribution of invasive alien plants of China among life forms

\begin{tabular}{lrrrrr}
\hline Life form & IE & NE & IE/NE & Total & $\%$ \\
\hline Annual & 25 & 91 & 0.27 & 116 & 43.0 \\
Annual or biennial & 3 & 9 & 0.33 & 12 & 4.4 \\
Biennial & 4 & 7 & 0.57 & 11 & 4.1 \\
Herbaceous perennial & 40 & 42 & 0.95 & 82 & 30.4 \\
Climber & 10 & 3 & 3.30 & 13 & 4.8 \\
Shrub & 7 & 9 & 0.78 & 16 & 5.9 \\
Tree & 4 & 6 & 0.67 & 10 & 3.7 \\
Free floating aquatic & 2 & 3 & 0.67 & 5 & 1.8 \\
Succulent & 3 & 2 & 1.50 & 5 & 1.8 \\
\hline
\end{tabular}

$\mathrm{IE}=$ invasive elsewhere, $\mathrm{NE}=$ not invasive elsewhere. Percentage refers to whole dataset

plants, aquatic plants only $1.8 \%$. Herbs (annual to perennial) amounted to $81.9 \%$ of all species. The succulent species were members of Opuntia and Bryophyllum.

The invasive plant species were prevalent in disturbed grounds and in agricultural areas (Fig. 6). Species growing in ruderal sites (habitat type 1 in Fig. 6) were mostly not considered as being invasive 


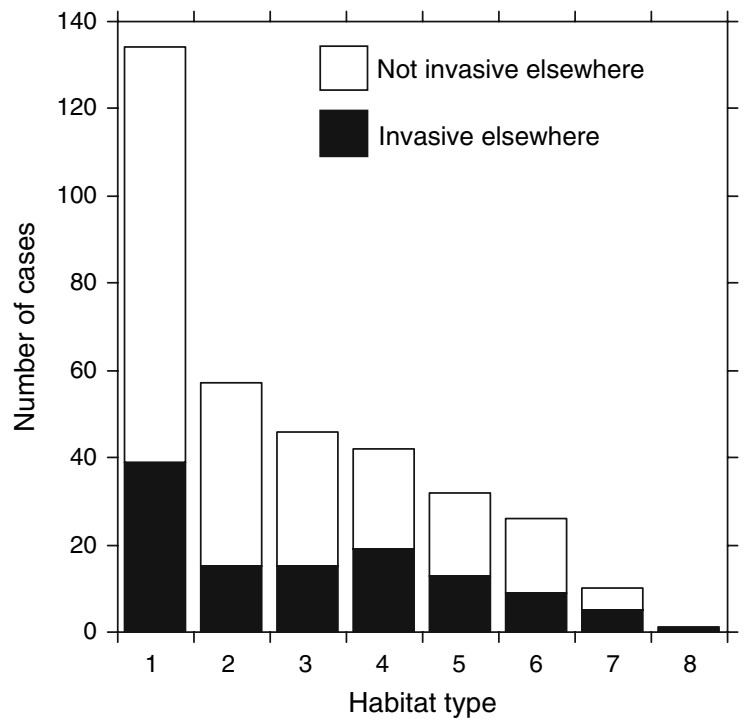

Fig. 6 Number of invasive alien plant species $(N=181)$ in various habitats of China. Species may occur in more than one habitat type. Habitats: $1=$ Roadsides, railways, waste places, disturbed ground; 2 = agricultural areas, fields; $3=$ grasslands, pastures, grassy slopes; $4=$ tree plantations, afforestations; $5=$ Lakeshores, riparian habitats; $6=$ natural forests and forest margins; $7=$ coastal areas; $8=$ swamps, marshes

elsewhere. The relatively higher proportion of species invasive elsewhere was evident in species colonizing afforestations, tree plantations, and coastal areas. Thus, the ranking of species richness among habitats was different between species being invasive elsewhere and species not being invasive elsewhere.

\section{Economic uses}

The profile of economic uses demonstrates the prevalence of ornamentals among invasive plant species in China (Fig. 7). The 94 ornamentals identified included species from 75 genera and 40 families. The second most frequent economic use was medicinal plants. These species were made of $54 \%$ annuals, and the families Asteraceae and Brassicaceae contributed each with 11 species. Plants used as fodder or forage included 14 grass species but also species such as Alternanthera philoxeroides and Eichhornia crassipes. Among turf grasses, most of the species were also invasive elsewhere. The proportion of species not considered as invasive

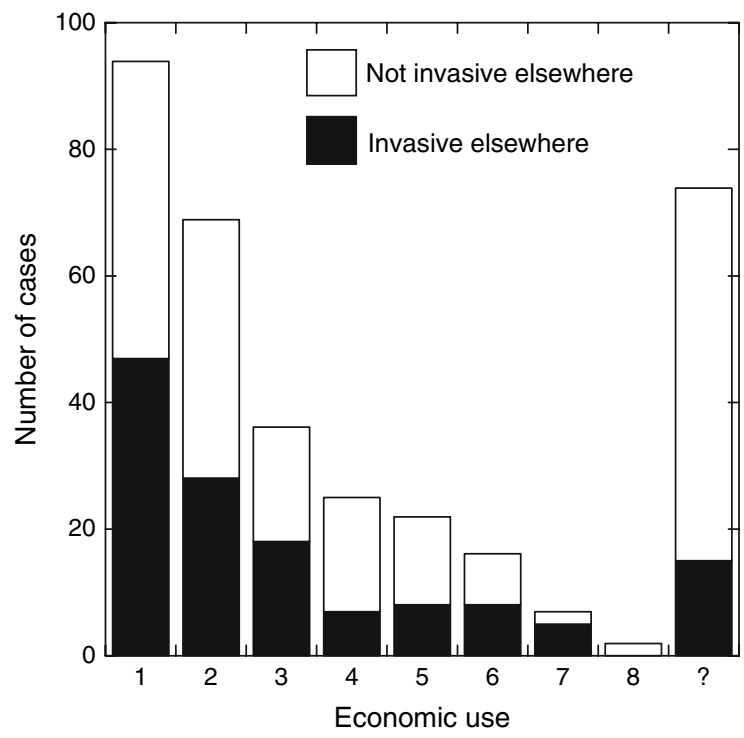

Fig. 7 Economic uses of invasive plant species $(N=270)$ of China. Medicinal plants include species that are used in folklore and species used for remedies. Invasive elsewhere refers to being harmful to natural areas (see text for explanations). Species may have been allocated to more than one category. $1=$ ornamentals, $2=$ medicinal plants, $3=$ Fodder and forage, $4=$ Food plants, $5=$ Various materials, $6=$ erosion control and soil improvement, $7=$ turgrasses, $8=$ other ises, ? = unknown or weed

elsewhere was the highest in food plants. The proportion of species being invasive elsewhere was higher in ornamentals than in non-ornamentals $\left(\chi^{2}=11.6, \quad P<0.001\right)$. Weeds or species with unknown economic uses consisted of $65 \%$ annuals.

\section{Discussion}

Available data and species numbers

Compiling alien species for a given country has proved to be a useful approach to understanding plant invasion patterns (Rozefelds et al. 1999; Stadler et al. 2000; Silva and Smith 2004; Khuroo et al. 2007) and is the first step towards developing a management strategy for invasive species. Because we focused on invasive species, our species list certainly represents only a fraction of all naturalized alien plants within China's territories. Having such data would be indispensable but is currently not feasible to obtain. This represents a major gap of knowledge to be filled, 
since complete floristic inventories of alien plants are essential for studying plant invasions (Pyšek et al. 2004).

Our data represent the current species pool of invasive plants and hence a snapshot in time. Since alien species spread and new species introductions are taking place, any floristic and biogeographic pattern will inevitably change over time. Previously published numbers of invasive plants in China differ markedly, e.g. 108 (Qiang and Cao 2000), 126 (Liu et al. 2006), 188 (Xu et al. 2006b). These differences are likely to reflect the dynamics of species naturalization as well as degree of knowledge. The list of Liu et al. (2005) does not include important invaders such as Agave americana, Asparagus densiflorus or Robinia pseudoacacia. We believe that our list represents the currently most updated compilation of invasive plant species in China.

The 270 invasive alien plant species make $0.9 \%$ of China's flora. The figure appears to be low compared to other regions. In California, for example, about 70 plant species are considered as serious invaders (Bossard et al. 2000), corresponding to $1.6 \%$ of the state's flora. The same has been observed for Taiwan, which has a much lower number of alien plants compared to Hawaii (8.1 and $43.8 \%$, respectively, $\mathrm{Wu}$ et al. 2004b). Although plant introductions have a long history in China (Xie et al. 2001), large-scale introductions of species from other continents are a rather recent phenomenon and have probably not yet achieved the quantities of other regions in the world. The invasive perennial Solidago canadensis for example has been introduced into China in 1935 (Jin et al. 2004), whereas in Europe, the same plant was brought from North America in the 17th century (Weber 1998). According to Ding and Xie (1996), 837 plant species have been introduced into China up to 1970 . International trade in China became important since the 1980 s only but is now increasing rapidly (Normile 2004).

Status of species elsewhere and habitats

About one-third of the species reported here are serious invaders of natural areas in places outside of China, implying that there is considerable potential for damage to ecosystems in China. Whether those plant species are behaving similarly in China than in other parts of the world is an open question that merits further investigations. Some species (e.g. Ochrosia elliptica, Tradescantia zebrina, Voacanga africana) are rather unknown as weeds or invaders in other parts of the world. More data on their ecology and impacts on ecosystems in China are needed, as such species may become new threats if introduced to other regions.

The fact that most plant species identified here are not serious invaders of natural habitats in other regions than China may reflect that these are primarily agricultural weeds; the majority of the species reported here occurred indeed on disturbed grounds and in arable fields. However, other habitat types representing more natural vegetation (forests, lake shores, wetlands) do also have a high fraction of species not being invaders of natural areas outside of China. Our categorization of habitats may be too broad to show whether these species are penetrating into undisturbed vegetation or whether they are confined to disturbed sites within these habitat types.

\section{Life forms}

The life form distribution among invasive plants was characterized by a high fraction of annuals and a remarkably low number of woody perennials. Whereas the high proportion of annuals in our dataset corresponds to other findings, e.g. Taiwan (Wu et al. 2004b), the number of woody taxa is likely to be underestimated. The reasons are most likely the lack of surveys and recordings of alien species in China. In other regions, shrubs and trees contribute greatly to the number of invasive alien plants (Binggeli 1996). We assume that there are many more woody naturalized species in China, for example Pinus sp., Acacia sp., and Eucalyptus sp. Pines and eucalypt trees are widely planted in China and are frequently escaping (S. Qiang, pers. comm.), and species of both genera are serious invaders in other regions (Richardson and Rejmánek 2004; Weber 2003). Pinus radiata, highly invasive in South Africa where it displaces species-rich native shrublands (Richardson and Brown 1986; Lavery and Mead 1998) is currently being evaluated as a tree for revegetating degraded lands and to reduce soil erosion (Yan et al. 2006). Whereas this is necessary, introducing and planting tree species that have proved to be damaging to 
natural environments in other regions should be undertaken with great caution (Binggeli 1996). Also, Casuarina equisetifolia, a highly invasive tree of coastal areas in Florida and the Caribbean (Weber 2003), has been introduced to China and is being cultivated (Zhong et al. 2005). The status of these trees in terms of their naturalization potential needs to be assessed.

Among the invasive trees identified here, a number of species did have profound impacts on natural ecosystems elsewhere, e.g. Leucaena leucocephala, Robinia pseudoacacia, Salix fragilis. The latter is frequently planted for reforestations in China (Flora of China 2007) and has proved to change riparian ecosystems in New Zealand (Lester et al. 1994). Among shrubs, three species are of particular interest, e.g. Acacia farnesiana, Chromolaena odorata, and Ulex europaeus. All three species are widespread invaders of natural areas (Cronk and Fuller 1995; Weber 2003). Whereas Chromolaena odorata is well known as an invader in mainland and Taiwan of China (Peng and Yang 1998; Xie et al. 2001), no studies have addressed the ecology of Acacia farnesiana and Ulex europaeus in China.

The high fraction of annuals in our list may reflect a high number of agricultural weeds. Annuals contributed most to species not being serious environmental weeds elsewhere, indicating that they are mainly weeds of disturbed grounds. The high fraction of annuals may also be due to the large area of China located at high elevations. The invasive plants of the four western provinces (Fig. 1), having high mean altitudes, consisted mostly of annuals and short-lived perennials.

\section{Taxonomy}

It is not surprising that most invasive plants belong to large families. Global family size is a predictor for the number of alien plants in a flora (Weber 1997; Daehler 1998; Pyšek 1998; Li et al. 2001), and Asteraceae and Poaceae are also among the major families in the naturalized flora of Chinese Taiwan of China (Wu et al. 2004b). In contrast to Chinese Taiwan, the family Brassicaceae is an important source of invasive plants in mainland China. Other families, e.g. Amaranthaceae, Euphorbiaceae, Solanaceae and Convolvulaceae, are well represented in alien floras of Asia (Zerbe et al. 2004; Wu et al. 2004b; Khuroo et al. 2007). The major genera contributing to invasive plants in China are also among the largest in the world, e.g. Ipomoea, Solanum, and Euphorbia. Some genera that provide many alien plants in Taiwan are missing in our list (e.g. Crotalaria, Rumex). However, many of the species in these genera are native to China. This is also the reason that Polygonum species did not appear in our list, although many species of Polygonum and Rumex are weedy in China (Li 1998).

Geographic origins and economic uses

As in most alien floras, species originated from all continents. However, South and North American species predominated among China's invasive plants, followed by Eurasian and African species. The profile of origins strongly resembles that of Europe's alien flora (Weber 1997) and the alien flora of Taiwan (Wu et al. 2004b). The large number of South American species invading Chinese habitats reflects the large area with a subtropical climate in this country.

Ornamentals contributed most to the invasive plants, which has been found for other countries and at a global scale (Reichard and White 2001; Mack and Erneberg 2002; Weber 2003). The large number of medical plants among the invasive flora is striking and makes the profile of economic uses different from that of other countries. One possibility might be that traditional Chinese medicine increasingly relies on alien species as native species become rarer. Overexploitation of native plants is one of the threats for rare species (López-Pujol et al. 2006). Well known invaders in this group include Alliaria petiolata or Ipomoea cairica. Grasses contributed mostly to forage and fodder plants but some species (e.g. Spartina spp.) have been planted for soil stabilizing.

Patterns of species richness of invasive plants within China

Within China, the proportion and number of invasive plants among provinces varies greatly. Overall, species richness and density of invasive plants among provinces were correlated with native species 
richness and density. This is in accordance with other studies (Stohlgren et al. 1999; Sax 2002; Deutschewitz et al. 2003), and the positive relationship is most likely to reflect habitat diversity (Chong et al. 2001). However, the large size variation of provinces may mask any clear relationships and smaller spatial units than provinces would seem necessary for establishing accurate relationships between native and alien species richness (Stohlgren et al. 2006). The correlation between endemic and invasive species richness is obvious because larger province floras contain more endemics but demonstrates potential threats to the conservation of rare species. Field observations strongly suggest that many endemics and their habitats are threatened by invasive species ( $\mathrm{Lu}$ et al. 2006).

Our regression analyses demonstrated that human population and native plant species richness are the best predictors for invasive plant species richness. These findings are similar to Liu et al. (2005), with the exception that in our study, latitude and longitude did not correlate with invasive species richness. However, Fig. 2 clearly suggests that southeastern provinces share more invasives than northwestern provinces. These are the most densely populated provinces and their ports recipients of international trade.

The variation in species richness also reflects China's markedly different topography, elevations, and climates (Ren 2000), so that a large diversity of habitats is given. It is therefore not surprising that the four biogeographic regions differ in their invasive floras. The western provinces Gansu, Qinghai, Xingjiang and Xizang (Tibet) are comprised of high plateaus and had the lowest similarity with the alien floras of the remaining biogeographic regions. It is, however, surprising that even there, the share of invasive plants includes 63 species, most of which are annual or short-lived herbs.

A number of invasive species in our list have been reported from high elevations, some of them occurring from sea level up to $2,500 \mathrm{~m}$ or more. Invasive plants growing in the western provinces are found at even higher elevations; the Qinghai-Tibet Plateau in the lower part of Western China has an average elevation of 4,000 $\mathrm{m}$ (Hou 1983). In other regions alien weeds have also been found to grow at high elevations (e.g. Pérez 1998; Daehler 2005; Khuroo et al. 2007).
The most widespread species included ornamentals (e.g. Ipomoea purpurea) and accidental introductions (e.g. Lolium temulentum). The latter entered China with the introduction of new wheat varieties (Ding and Xie 1996). Range sizes of alien plants are the product of species dispersal and human assisted dispersal, and some serious invaders have been planted. For example, the three aquatic plants Alternanthera philoxeroides, Eichhornia crassipes, Pistia stratiotes have been planted extensively throughout China in the 1950s because they were regarded as beneficial (Ding and Xie 1996). Thus, the distribution of any alien plant species cannot be understood without knowing their history.

\section{Outlook}

Many invasive plants in China are yet confined to few provinces and likely have not yet reached their distribution limits. This could be shown for Solidago canadensis, based on an estimation of its potential distribution range in China ( $\mathrm{Lu}$ et al. 2007). However, accurate data on the distribution are scarce, and systematic surveys are badly needed.

China's fast economic growth and increasing international trade will foster biological invasions and invasive species will inevitably become more important here (Weber and $\mathrm{Li}$, in press). Several authors stress that the increasing trade between eastern Asia and the United States will lead to the introduction of new invaders on both sides (Guo 2002; Callaway et al. 2006; Jenkins and Mooney 2006), asking for close collaborations between these nations. China, with its yet low number of invasive species may rely on experiences of other countries and take appropriate measures to counteract new invasions. It is therefore urgent to have baseline data on the invasive species pool in China and to accelerate research on invasive species. Needed are risk assessments of beneficial species intended for introduction. For example, in Liaoning province, a trial was conducted along a highway to control Ambrosia artemisiifolia by planting shrubs or large herbs (e.g. Amorpha fruticosa, Coronilla varia, Helianthus tuberosus) with the aim to replace rag weed (Ding and Xie 1996). However, all three species are alien to China and are serious invaders of natural areas elsewhere (Weber 2003). 
Distribution data for native and alien species at regional and local scales are necessary to draw conclusions on the invasion potential and on ecological damages by invasive alien species. Considering the extraordinary species richness and extent of endemism of China's flora, even at low elevations, the potential of serious impacts on native species is high. Punctual observations support this connotation; Mikania micrantha for example is rapidly spreading in southern China, smothering trees and shrubs, killing them and replacing the original species-rich vegetation (Zhuang 1999, cited in Qiang 2005). Similarly, crofton weed (Eupatorium adenophorum) covers now more than $300,000 \mathrm{~km}^{2}$ in southwestern China, invading forests, grasslands and decreasing biodiversity (Qiang 1998).
An increase of awareness and knowledge of invasive species in China is a prerequisite for setting up a national management strategy in the sense of McNeely et al. (2001). Intensified research on the ecology of invasive species in China and the development of proper control techniques seems necessary.

Acknowledgments This work was financially supported by the National Basic Research Program of China (grant No. 2006CB403305), the Natural Science Foundation of China (grant no. 30670330), the Ministry of Education of China (grant no. 105063) and Visiting Scholars Program of Fudan University. T. Stohlgren and two anonymous reviewers provided helpful comments to an earlier version of the manuscript.

\section{Appendix}

Appendix 1 Invasive alien plant species in China

\begin{tabular}{|c|c|c|c|c|c|}
\hline Species & Family & Lifeform & Origin or native range & Provinces & Habitats \\
\hline Acacia farnesiana & Fabaceae & Sh & NAm, SAm & 9 & \\
\hline Acanthospermum australe & Asteraceae & An & SAm & 2 & 1,5 \\
\hline Aegilops squarrosa & Poaceae & An & Eurasia & & 2,3 \\
\hline Aeschynomene indica & Fabaceae & An & NAm & 1 & \\
\hline Agave americana & Agavaceae & $\mathrm{Su}$ & NAm & 8 & 1,3 \\
\hline Ageratum conyzoides & Asteraceae & An & SAm & 13 & $1,2,4,5,7$ \\
\hline A. houstonianum & Asteraceae & An & CAm & & 1,2 \\
\hline Agrostemma githago & Caryophyllaceae & An & NAfr, Eurasia & 5 & $1,2,3$ \\
\hline Alliaria petiolata & Brassicaceae & An & Eurasia & 2 & $1,2,5,6$ \\
\hline Aloe vera & Liliaceae & $\mathrm{Su}$ & Afr & 1 & \\
\hline Alternanthera philoxeroides & Amaranthaceae & $\mathrm{Pe}$ & SAm & 19 & 1,5 \\
\hline A. pungens & Amaranthaceae & $\mathrm{Pe}$ & SAm & 4 & 1 \\
\hline Alyssum alyssoides & Brassicaceae & An & NAfr, Eurasia & 1 & 1 \\
\hline Amaranthus albus & Amaranthaceae & An & NAm & 3 & 1 \\
\hline A. blitoides & Amaranthaceae & An & NAm & & 1,2 \\
\hline A. caudatus & Amaranthaceae & An & SAm & & 1 \\
\hline A. hybridus & Amaranthaceae & An & SAm & 10 & 1,3 \\
\hline A. polygonoides & Amaranthaceae & An & CAm & 3 & 1 \\
\hline A. retroflexus & Amaranthaceae & An & SAm & 12 & 1 \\
\hline A. spinosus & Amaranthaceae & An & SAm & 7 & 1 \\
\hline A. tricolor & Amaranthaceae & An & Asia & & 1,2 \\
\hline A. viridis & Amaranthaceae & An & SAm & 21 & 1,2 \\
\hline Ambrosia artemisiifolia & Asteraceae & An & NAm & 17 & $1,2,4$ \\
\hline A. trifida & Asteraceae & An & NAm & 15 & $1,2,4$ \\
\hline Anredera cordifolia & Basellaceae & Vi & SAm & 6 & \\
\hline Anthemis arvensis & Asteraceae & An & NAfr, Eurasia & & 1,2 \\
\hline
\end{tabular}


Appendix 1 continued

\begin{tabular}{|c|c|c|c|c|c|}
\hline Species & Family & Lifeform & Origin or native range & Provinces & Habitats \\
\hline Apium leptophyllum & Apiaceae & An & SAm & 9 & $1,4,5$ \\
\hline Armoracia rusticana & Brassicaceae & $\mathrm{Pe}$ & Eur & 5 & 2 \\
\hline Asclepias curassavica & Asclepiadaceae & $\mathrm{Pe}$ & Tropics & 16 & 1,2 \\
\hline Asparagus densiflorus & Liliaceae & $\mathrm{Pe}$ & Afr & 28 & \\
\hline A. setaceus & Liliaceae & $\mathrm{Vi}$ & Afr & 28 & \\
\hline Aster subulatus & Asteraceae & An & NAm & 7 & 1 \\
\hline Atriplex nummularia & Chenopodiaceae & $\mathrm{Pe}$ & Aus & 1 & \\
\hline Axonopus compressus & Poaceae & $\mathrm{Pe}$ & NAm, SAm & 6 & $3,5,6$ \\
\hline Avena fatua & Poaceae & An & Afr, Eurasia & 32 & 1,3 \\
\hline A. sterilis & Poaceae & An & Afr, Eurasia & 1 & \\
\hline Bidens frondosa & Asteraceae & An & NAm & 5 & 1,4 \\
\hline B. pilosa & Asteraceae & An & SAm & 21 & 1 \\
\hline Brachiaria eruciformis & Poaceae & An & Afr, Eurasia & & 5 \\
\hline B. mutica & Poaceae & $\mathrm{Pe}$ & SAm & & $2,3,4$ \\
\hline B. plantaginea & Poaceae & $\mathrm{Pe}$ & Afr, SAm & 1 & \\
\hline Brassica juncea & Brassicaceae & An & Asia & 28 & 1,2 \\
\hline B. kaber & Brassicaceae & An & Eur & & 2 \\
\hline B. rapa subs. campestris & Brassicaceae & An & $?$ & 1 & \\
\hline B. tournefortii & Brassicaceae & An & Afr, Eurasia & 1 & \\
\hline Bromus catharticus var. catharticus & Poaceae & An & SAm & & 5 \\
\hline Bryophyllum pinnatum & Crassulaceae & $\mathrm{Su}$ & Afr & 5 & \\
\hline Buchloe dactyloides & Poaceae & $\mathrm{Pe}$ & NAm & & 1,3 \\
\hline Cabomba caroliniana & Cabombaceae & $\mathrm{Aq}$ & SAm & 3 & 5 \\
\hline Callisia repens & Commelinaceae & $\mathrm{Pe}$ & NAm, SAm & 1 & 1 \\
\hline Cameraria latifolia & Apocynaceae & $\operatorname{Tr}$ & NAm, SAm & 1 & \\
\hline Cannabis sativa & Cannabaceae & An & Asia & 1 & 2 \\
\hline Capsella bursa-pastoris & Brassicaceae & An & $?$ & 28 & $1,2,3$ \\
\hline Cassia mimosoides & Fabaceae & An & Tropics & & 1,2 \\
\hline C. occidentalis & Fabaceae & An & Tropics & & 1,5 \\
\hline C. tora & Fabaceae & Sh & Asia & & 1,5 \\
\hline Catharanthus roseus & Apocynaceae & $\mathrm{Pe}$ & Afr & 8 & \\
\hline Cenchrus echinatus & Poaceae & An & Tropics & 5 & \\
\hline C. pauciflorus & Poaceae & An & NAm, SAm & & \\
\hline Centaurea cyanus & Asteraceae & An & Eurasia & 1 & \\
\hline Chenopodium ambrosioides & Chenopodiaceae & $\mathrm{Pe}$ & NAm, SAm & 10 & 1 \\
\hline C. giganteum & Chenopodiaceae & An & Asia & 12 & \\
\hline C. hybridum subsp. hybridum & Chenopodiaceae & An & Eurasia & 18 & 3,6 \\
\hline Chromolaena odorata & Asteraceae & Sh & CAm, SAm & 6 & $1,4,5$ \\
\hline Chrysanthemum carinatum & Asteraceae & An & NAfr & & 1,2 \\
\hline C. coronarium & Asteraceae & An & NAfr, Eurasia & & 1,5 \\
\hline Conium maculatum & Apiaceae & An & Afr, Eurasia & 1 & 2,6 \\
\hline Conyza bonariensis & Asteraceae & An & SAm & 12 & 1,4 \\
\hline C. canadensis & Asteraceae & An & NAm, SAm & 28 & $1,2,3,5$ \\
\hline C. sumatrensis & Asteraceae & An & SAm & 13 & \\
\hline Cordyline fruticosa & Liliaceae & $\mathrm{Pe}$ & $?$ & 4 & \\
\hline
\end{tabular}


Appendix 1 continued

\begin{tabular}{|c|c|c|c|c|c|}
\hline Species & Family & Lifeform & Origin or native range & Provinces & Habitats \\
\hline Coreopsis grandiflora & Asteraceae & $\mathrm{Pe}$ & NAm & & 1,4 \\
\hline C. lanceolata & Asteraceae & $\mathrm{Pe}$ & NAm & & 3,4 \\
\hline C. tinctoria & Asteraceae & An & NAm & 2 & 1,2 \\
\hline Coriandrum sativum & Apiaceae & An & Eur & & 1,4 \\
\hline Coronopus didymus & Brassicaceae & An & SAm & 11 & 1,4 \\
\hline Cosmos bipinnatus & Asteraceae & An & CAm, SAm & & 3,4 \\
\hline C. sulphureus & Asteraceae & An & CAm, SAm & & $1,3,4$ \\
\hline Crassocephalum crepidioides & Asteraceae & An & Afr & 15 & \\
\hline Cyclachaena xanthiifolia & Asteraceae & An & NAm & 1 & \\
\hline Cyperus rotundus & Cyperaceae & $\mathrm{Pe}$ & Tropics & 29 & \\
\hline Datura inoxia & Solanaceae & An & CAm & 1 & \\
\hline D. metel & Solanaceae & An & NAm & 7 & 1,3 \\
\hline D. stramonium & Solanaceae & An & CAm & 27 & 1,3 \\
\hline Daucus carota & Apiaceae & $\mathrm{Pe}$ & Afr, Eurasia & 8 & 1,3 \\
\hline Deutzia crenata & Hydrangeaceae & $\mathrm{Sh}$ & Asia & 7 & \\
\hline Digitalis purpurea & Scrophulariaceae & $\mathrm{Pe}$ & NAfr, Eur & 4 & 1 \\
\hline Digitaria ciliaris & Poaceae & An & $?$ & 1 & \\
\hline Diplotaxis muralis & Brassicaceae & An & NAfr, Eurasia & 1 & 7 \\
\hline Duranta erecta & Verbenaceae & Sh & NAm, SAm & 8 & 1 \\
\hline Ehrharta erecta & Poaceae & An & Afr & & 1 \\
\hline Eichhornia crassipes & Pontederiaceae & $\mathrm{Aq}$ & SAm & 19 & 5 \\
\hline Eleusine indica & Poaceae & $\mathrm{Pe}$ & Paleotropics & 30 & \\
\hline Elsholtzia communis & Lamiaceae & $\mathrm{Pe}$ & $?$ & 1 & \\
\hline Erigeron annuus & Asteraceae & An & NAm & 28 & 1,4 \\
\hline E. philadelphicus & Asteraceae & $\mathrm{Pe}$ & NAm & 6 & 1,6 \\
\hline Eryngium foetidum & Apiaceae & $\mathrm{Pe}$ & SAm & 5 & $1,5,6$ \\
\hline Etlingera elatior & Zingiberaceae & $\mathrm{Pe}$ & Asia & 1 & 6 \\
\hline Eupatorium adenophorum & Asteraceae & $\mathrm{Pe}$ & CAm & 5 & $1,2,3,4$ \\
\hline E. catarium & Asteraceae & An & SAm & 2 & \\
\hline Euphorbia dentata & Euphorbiaceae & An & CAm, NAm & 1 & \\
\hline E. hirta & Euphorbiaceae & An & Tropics & 8 & \\
\hline E. maculata & Euphorbiaceae & An & NAm & 9 & \\
\hline E. marginata & Euphorbiaceae & An & NAm & 1 & \\
\hline Eutrema wasabi & Brassicaceae & $\mathrm{Pe}$ & Asia & 1 & 5 \\
\hline Evolvulus nummularius & Convolvulaceae & $\mathrm{Pe}$ & $?$ & 1 & 1 \\
\hline Galinsoga parviflora & Asteraceae & An & CAm, SAm & 27 & $1,4,5$ \\
\hline Geranium carolinianum & Geraniaceae & An & CAm, NAm & 11 & \\
\hline Gomphrena celosioides & Amaranthaceae & An & SAm & 3 & 1 \\
\hline Helenium autumnale & Asteraceae & $\mathrm{Pe}$ & NAm & 1 & 1 \\
\hline Helianthus anпuиs & Asteraceae & An & NAm & 1 & \\
\hline H. petiolaris & Asteraceae & An & NAm & 1 & \\
\hline H. tuberosus & Asteraceae & $\mathrm{Pe}$ & NAm & & $1,4,5$ \\
\hline Heliotropium europaeum & Boraginaceae & An & NAfr, Eurasia & 3 & $1,2,5$ \\
\hline Hesperis matronalis & Brassicaceae & An & Eurasia & 1 & \\
\hline Hibiscus trionum & Malvaceae & An & Afr, Eurasia & 25 & 1,4 \\
\hline
\end{tabular}


Appendix 1 continued

\begin{tabular}{|c|c|c|c|c|c|}
\hline Species & Family & Lifeform & Origin or native range & Provinces & Habitats \\
\hline Hyptis rhomboidea & Lamiaceae & An & CAm & 4 & 1 \\
\hline H. suaveolens & Lamiaceae & An & SAm & 5 & 1 \\
\hline Ipomoea alba & Convolvulaceae & $\mathrm{Vi}$ & NAm, SAm & 9 & $1,5,6$ \\
\hline I. cairica & Convolvulaceae & $\mathrm{Vi}$ & $?$ & 6 & 1 \\
\hline I. carnea & Convolvulaceae & $\mathrm{Sh}$ & NAm, SAm & 3 & \\
\hline I. hederacea & Convolvulaceae & $\mathrm{Vi}$ & NAm, SAm & 1 & \\
\hline I. indica & Convolvulaceae & $\mathrm{Vi}$ & Pantropic & 3 & 6,7 \\
\hline I. lacunosa & Convolvulaceae & $\mathrm{Vi}$ & NAm & 1 & \\
\hline I. nil & Convolvulaceae & An & Pantropic & 24 & 1,3 \\
\hline I. purpurea & Convolvulaceae & $\mathrm{Vi}$ & SAm & 27 & $1,2,5,6$ \\
\hline Jacquemontia tamnifolia & Convolvulaceae & An & NAm, SAm & 1 & \\
\hline Lantana camara & Verbenaceae & $\mathrm{Sh}$ & SAm & 6 & $1,4,7$ \\
\hline Lemna trinervis & Lemnaceae & $\mathrm{Aq}$ & NAm, SAm & 3 & \\
\hline Lepidium campestre & Brassicaceae & An & Eurasia & 1 & $1,2,3$ \\
\hline L. densiflorum & Brassicaceae & An & NAm & & $1,5,7$ \\
\hline L. sativum & Brassicaceae & An & NAfr, Asia & 6 & \\
\hline L. virginicum & Brassicaceae & An & CAm, NAm & 19 & $1,2,3,4$ \\
\hline Leucaena leucocephala & Fabaceae & $\operatorname{Tr}$ & SAm & 9 & \\
\hline Leucanthemum vulgare & Asteraceae & $\mathrm{Pe}$ & Eurasia & & 4 \\
\hline Lilium hansonii & Liliaceae & $\mathrm{Pe}$ & Asia & 1 & 5 \\
\hline Linum usitatissimum & Linaceae & An & $?$ & 1 & \\
\hline Lobularia maritima & Brassicaceae & $\mathrm{Pe}$ & NAfr, Eurasia & 9 & 1 \\
\hline Lolium multiflorum & Poaceae & An & NAfr, Eurasia & 16 & $1,2,3$ \\
\hline L. perenne & Poaceae & $\mathrm{Pe}$ & NAfr, Eurasia & & 4 \\
\hline L. persicum & Poaceae & An & Asia & & 2 \\
\hline L. temulentum & Poaceae & An & Eur & 30 & 2 \\
\hline Macfadyena unguis-cati & Bignoniaceae & $\mathrm{Vi}$ & CAm, SAm & 2 & \\
\hline Malvastrum coromandelianum & Malvaceae & $\mathrm{Pe}$ & Pantropic & 6 & 1,4 \\
\hline Martynia annua & Pedaliaceae & $\mathrm{Pe}$ & CAm, SAm & 1 & 1,6 \\
\hline Medicago hispida & Fabaceae & An & NAfr, Eurasia & & 1,4 \\
\hline Mikania micrantha & Asteraceae & $\mathrm{Vi}$ & CAm, SAm & 1 & $1,4,6$ \\
\hline Mimosa invisa & Fabaceae & $\mathrm{Pe}$ & SAm & 2 & \\
\hline M. pudica & Fabaceae & $\mathrm{Pe}$ & SAm & 6 & 1,6 \\
\hline Mirabilis jalapa & Nyctaginaceae & An & SAm & 18 & 1 \\
\hline Narcissus tazetta & Amaryllidaceae & $\mathrm{Pe}$ & NAfr, Eurasia & 2 & 1 \\
\hline Nasturtium officinale & Brassicaceae & $\mathrm{Pe}$ & NAfr, Eurasia & 18 & 5,8 \\
\hline Nerium oleander & Apocynaceae & $\operatorname{Tr}$ & Afr, Eurasia & 1 & \\
\hline Nicandra physalodes & Solanaceae & An & Sam & 7 & 1 \\
\hline Nymphaea alba & Nymphaeaceae & $\mathrm{Aq}$ & NAfr, Eurasia & 4 & 5 \\
\hline Ochrosia elliptica & Apocynaceae & $\operatorname{Tr}$ & Aus, Pac & 2 & \\
\hline Oenothera erythrosepala & Onagraceae & An & Eur & & 4,5 \\
\hline O. rosea & Onagraceae & $\mathrm{Pe}$ & CAm, SAm & 3 & \\
\hline Opuntia ficus-indica & Cactaceae & $\mathrm{Su}$ & CAm & 5 & 1,2 \\
\hline O. monacantha & Cactaceae & $\mathrm{Su}$ & SAm & 5 & 6 \\
\hline O. stricta var dillenii & Cactaceae & $\mathrm{Su}$ & NAm, SAm & 3 & \\
\hline
\end{tabular}


Appendix 1 continued

\begin{tabular}{|c|c|c|c|c|c|}
\hline Species & Family & Lifeform & Origin or native range & Provinces & Habitats \\
\hline Orobanche brassicae & Orobanchaceae & An & $?$ & 1 & \\
\hline Oxalis corymbosa & Oxalidaceae & $\mathrm{Pe}$ & SAm & 12 & 4 \\
\hline Panicum maximum & Poaceae & $\mathrm{Pe}$ & Afr & 6 & \\
\hline Papaver nudicaule & Papaveraceae & $\mathrm{Pe}$ & Eur & 8 & \\
\hline Parthenium hysterophorus & Asteraceae & An & CAm, SAm & 6 & 2,3 \\
\hline Parthenocissus quinquefolia & Vitaceae & $\mathrm{Vi}$ & CAm, NAm & & 4,6 \\
\hline Paspalum conjugatum & Poaceae & $\mathrm{Pe}$ & SAm & 11 & \\
\hline P. dilatatum & Poaceae & $\mathrm{Pe}$ & SAm & 4 & $1,2,3$ \\
\hline P. fimbriatum & Poaceae & An & CAm, SAm & & 1 \\
\hline Passiflora foetida & Passifloraceae & $\mathrm{Vi}$ & NAm, SAm & 6 & \\
\hline Pennisetum glaucum & Poaceae & An & $?$ & 1 & \\
\hline$P$. setosum & Poaceae & $\mathrm{Pe}$ & Tropics & & 3 \\
\hline Peperomia pellucida & Piperaceae & An & SAm & 5 & $2,6,7$ \\
\hline Persicaria pensylvanica & Polygonaceae & An & NAm & 1 & \\
\hline Phalaris minor & Poaceae & An & NAfr, Eurasia & & 2,4 \\
\hline P. paradoxa & Poaceae & An & NAfr, Eurasia & & \\
\hline Physalis peruviana & Solanaceae & $\mathrm{Pe}$ & SAm & 4 & 1 \\
\hline$P$. philadelphica & Solanaceae & An & CAm & 2 & 1,3 \\
\hline P. pubescens & Solanaceae & An & NAm, SAm & 3 & 1,6 \\
\hline Phytolacca americana & Phytolaccaceae & $\mathrm{Pe}$ & NAm & 18 & 1,6 \\
\hline Pilea microphylla & Urticaceae & An & CAm, SAm & 6 & \\
\hline Pistia stratiotes & Araceae & $\mathrm{Aq}$ & Afr, SAm & 17 & \\
\hline Pittosporum tobira & Pittosporaceae & $\operatorname{Tr}$ & Asia & 10 & $1,3,6,7$ \\
\hline Plantago aristata & Plantaginaceae & An & NAm & 1 & \\
\hline P. lanceolata & Plantaginaceae & $\mathrm{Pe}$ & NAfr, Eurasia & & 5,7 \\
\hline$P$. virginica & Plantaginaceae & An & NAm & 10 & $1,2,5$ \\
\hline Poa compressa & Poaceae & $\mathrm{Pe}$ & NAfr, Eurasia & & 1,3 \\
\hline Polymnia uvedalia & Asteraceae & $\mathrm{Pe}$ & NAm & 1 & \\
\hline Pseudelephantopus spicatus & Asteraceae & $\mathrm{Pe}$ & CAm, SAm & & 1,3 \\
\hline Pyrethrum parthenifolium & Asteraceae & $\mathrm{Pe}$ & Eurasia & & 1 \\
\hline Ranunculus arvensis & Ranunculaceae & An & NAfr, Eurasia & 2 & 1,4 \\
\hline$R$. muricatus & Ranunculaceae & An & NAfr, Eurasia & 3 & $1,2,3$ \\
\hline R. sardous & Ranunculaceae & An & NAfr, Eurasia & 1 & 1 \\
\hline R. trachycarpus & Ranunculaceae & An & $?$ & 1 & 3 \\
\hline Raphanus raphanistrum & Brassicaceae & An & NAfr, Eurasia & 3 & 1,2 \\
\hline Rapistrum rugosum & Brassicaceae & An & NAfr, Eurasia & 1 & 1 \\
\hline Rauvolfia cubana & Apocynaceae & Sh & CAm & 1 & \\
\hline Reseda lutea & Resedaceae & An & NAfr, Eurasia & 1 & 1,3 \\
\hline Rhus typhina & Anacardiaceae & $\operatorname{Tr}$ & NAm & 1 & \\
\hline Rhynchelytrum repens & Poaceae & $\mathrm{Pe}$ & Afr, Asia & 4 & \\
\hline Ribes multiflorum & Grossulariaceae & Sh & Eur & 6 & \\
\hline R. nigrum & Grossulariaceae & $\mathrm{Sh}$ & Eurasia & 3 & 1,6 \\
\hline R. uva-crispa & Grossulariaceae & Sh & NAfr, Eurasia & 6 & 1 \\
\hline Ricinus communis & Euphorbiaceae & An & Afr & 25 & $4,5,6$ \\
\hline Robinia pseudoacacia & Fabaceae & $\operatorname{Tr}$ & NAm & & 1,6 \\
\hline
\end{tabular}


Appendix 1 continued

\begin{tabular}{|c|c|c|c|c|c|}
\hline Species & Family & Lifeform & Origin or native range & Provinces & Habitats \\
\hline Rosmarinus officinalis & Lamiaceae & $\mathrm{Sh}$ & NAfr, Eurasia & 28 & \\
\hline Salix fragilis & Salicaceae & $\operatorname{Tr}$ & Eurasia & 3 & \\
\hline Salvia coccinea & Lamiaceae & An & NAm, SAm & 1 & \\
\hline Saponaria officinalis & Caryophyllaceae & $\mathrm{Pe}$ & Eurasia & 1 & 1 \\
\hline Scoparia dulcis & Scrophulariaceae & An & SAm & 6 & 1,4 \\
\hline Senecio dubtabilis & Asteraceae & An & Eur & 6 & \\
\hline S. vulgaris & Asteraceae & An & Cosmopolitan & 15 & $1,2,3$ \\
\hline Sesbania exaltata & Fabaceae & $\mathrm{Pe}$ & NAm & 1 & \\
\hline Setaria palmifolia & Poaceae & $\mathrm{Pe}$ & Asia & 2 & 1 \\
\hline S. parviflora & Poaceae & $\mathrm{Pe}$ & NAm, SAm & 1 & \\
\hline Sida rhombifolia & Malvaceae & $\mathrm{Pe}$ & Pantropic & 1 & \\
\hline S. spinosa & Malvaceae & $\mathrm{Pe}$ & Pantropic & 1 & \\
\hline Silybum marianum & Asteraceae & An & NAfr, Eur & & $1,2,4$ \\
\hline Sinapis alba & Brassicaceae & An & NAfr, Eurasia & 9 & 1,3 \\
\hline Sisymbrium altissimum & Brassicaceae & An & Eurasia & 3 & $1,2,3$ \\
\hline Solanum aculeatissimum & Solanaceae & An & SAm & 12 & $1,3,6$ \\
\hline S. capsicoides & Solanaceae & $\mathrm{Pe}$ & SAm & 9 & 1,6 \\
\hline S. chrysotrichum & Solanaceae & $\mathrm{Sh}$ & CAm, SAm & 2 & \\
\hline S. erianthum & Solanaceae & $\mathrm{Sh}$ & NAm, SAm & 9 & 1 \\
\hline S. seaforthianum & Solanaceae & $\mathrm{Vi}$ & NAm, SAm & 1 & 1 \\
\hline S. sisymbriifolium & Solanaceae & An & SAm & 2 & \\
\hline S. torvum & Solanaceae & $\mathrm{Pe}$ & CAm, SAm & 8 & 1 \\
\hline Solidago canadensis & Asteraceae & $\mathrm{Pe}$ & NAm & 6 & 1,4 \\
\hline Soliva anthemifolia & Asteraceae & An & SAm & 7 & $1,2,4$ \\
\hline Sorghum almum & Poaceae & $\mathrm{Pe}$ & SAm & 1 & \\
\hline S. halepense & Poaceae & $\mathrm{Pe}$ & NAfr, Asia & 15 & 1 \\
\hline S. sudanense & Poaceae & An & Afr & & 1,2 \\
\hline Spartina alterniflora & Poaceae & $\mathrm{Pe}$ & NAm, SAm & 4 & 7 \\
\hline S. anglica & Poaceae & $\mathrm{Pe}$ & Eur & 11 & 7 \\
\hline Spergula arvensis & Caryophyllaceae & An & NAfr, Eurasia & 5 & 3,5 \\
\hline Spermacoce latifolia & Rubiaceae & $\mathrm{Pe}$ & SAm & 4 & \\
\hline Stachytarpheta jamaicensis & Verbenaceae & $\mathrm{Pe}$ & CAm, SAm & 6 & 3 \\
\hline Stellaria apetala & Caryophyllaceae & An & Eur & 4 & 1,2 \\
\hline Symphytum officinale & Boraginaceae & $\mathrm{Pe}$ & Eurasia & 1 & 6 \\
\hline Synedrella nodiflora & Asteraceae & An & CAm, SAm & 6 & 1 \\
\hline Tagetes erecta & Asteraceae & An & CAm, SAm & & 1 \\
\hline T. patula & Asteraceae & An & CAm, SAm & & 1 \\
\hline Talinum paniculatum & Portulacaceae & An & NAm, SAm & & 1,5 \\
\hline Tectona grandis & Lamiaceae & $\operatorname{Tr}$ & Asia, Pac & 5 & \\
\hline Tithonia diversifolia & Asteraceae & $\mathrm{Pe}$ & CAm & & 1,4 \\
\hline Tradescantia spathacea & Commelinaceae & $\mathrm{Pe}$ & SAm & 1 & \\
\hline T. zebrina & Commelinaceae & $\mathrm{Pe}$ & CAm & 4 & \\
\hline Tridax procumbens & Asteraceae & $\mathrm{Pe}$ & CAm, SAm & 5 & 1,4 \\
\hline Trifolium hybridum & Fabaceae & $\mathrm{Pe}$ & NAfr, Eurasia & 1 & \\
\hline T. incarnatum & Fabaceae & An & Eur & & $1,2,3$ \\
\hline
\end{tabular}


Appendix 1 continued

\begin{tabular}{|c|c|c|c|c|c|}
\hline Species & Family & Lifeform & Origin or native range & Provinces & Habitats \\
\hline T. pratense & Fabaceae & $\mathrm{Pe}$ & NAfr, Eurasia & & $1,2,3$ \\
\hline T. repens & Fabaceae & $\mathrm{Pe}$ & NAfr, Eurasia & 23 & $1,2,3$ \\
\hline Ulex europaeus & Fabaceae & Sh & Eur & 1 & 1,3 \\
\hline Vaccaria segetalis & Caryophyllaceae & An & NAfr, Eurasia & 8 & 2 \\
\hline Veronica arvensis & Scrophulariaceae & An & NAfr, Eurasia & 9 & $1,3,4$ \\
\hline V. hederifolia & Scrophulariaceae & An & NAfr, Eurasia & 2 & 1,2 \\
\hline$V \cdot$ peregrina & Scrophulariaceae & An & NAm, SAm & 18 & 1 \\
\hline$V \cdot$ persica & Scrophulariaceae & An & Asia & 16 & 1,2 \\
\hline$V \cdot$ polita & Scrophulariaceae & An & NAfr, Eurasia & 20 & 1 \\
\hline Vetiveria zizanioides & Poaceae & $\mathrm{Pe}$ & Asia & 7 & \\
\hline Vinca minor & Apocynaceae & $\mathrm{Pe}$ & Eur & 1 & \\
\hline Voacanga africana & Apocynaceae & $\operatorname{Tr}$ & Afr & 1 & \\
\hline Waltheria indica & Sterculiaceae & Sh & NAm, SAm & 6 & \\
\hline Wedelia trilobata & Asteraceae & $\mathrm{Pe}$ & CAm, SAm & 4 & 1,3 \\
\hline Xanthium spinosum & Asteraceae & An & SAm & 4 & 1,4 \\
\hline$X$. strumarium & Asteraceae & An & CAm, SAm & 1 & 1 \\
\hline Zephyranthes candida & Amaryllidaceae & $\mathrm{Pe}$ & SAm & 8 & \\
\hline Z. carinata & Amaryllidaceae & $\mathrm{Pe}$ & CAm & 8 & \\
\hline Zinnia peruviana & Asteraceae & An & NAm, SAm & & 1,3 \\
\hline
\end{tabular}

Names in bold indicate species that are invasive in natural areas in other countries than China. Lifeform: An = annual or short-lived perennial herb, $\mathrm{Aq}=$ aquatic plant, $\mathrm{Pe}=$ perennial herb, $\mathrm{Sh}=$ shrub, $\mathrm{Su}=$ succulent, $\mathrm{Tr}=\mathrm{tree}, \mathrm{Vi}=$ vine or liana. Origins: Afr $=$ Africa, Aus = Australia, Eur $=$ Europe, CAm $=$ Central America, NAm = North America, SAm = South America, NAfr $=$ North Africa, Pac = Pacific, ? = unknown. Provinces: number of provinces in which the species is present. Habitats: 1 = roadsides, railways, waste places, disturbed ground; $2=$ agricultural areas, fields; 3 = grasslands, pastures, grassy slopes; $4=$ tree plantations, afforestations; $5=$ lakeshores, riparian habitats; $6=$ natural forests and forest margins; $7=$ coastal areas; $8=$ swamps, marshes

\section{References}

Binggeli P (1996) A taxonomic, biogeographical and ecological overview of invasive woody plants. J Veg Sci 7: $121-124$

Bossard CC, Randall JM, Hoshovsky MC (2000) Invasive plants of California's wildlands. University of California Press, Berkeley

Callaway RM, Miao SL, Guo Q (2006) Are trans-Pacific invasions the new wave? Biol Invasions 8:1435-1437

Chen HL, Li YJ, Li B, Chen JL, Wu J (2005) Impacts of exotic plant invasions on soil biodiversity and ecosystem processes. Biodivers Sci 13:555-565

Chong GW, Reich RM et al (2001) New approaches for sampling and modeling native and exotic plant species richness. West N Am Nat 61:328-335

Convention on Biological Diversity (2002) Assessing the impact of trade liberalization on the conservation and sustainable use of agricultural biological diversity. Convention on biological diversity (CBD), The Hague

Corlett RT (1988) The naturalized flora of Singapore. J Biogeogr 15:657-663
Corlett RT (1992) The naturalized flora of Hong Kong: a comparison with Singapore. J Biogeogr 19:421-430

Cronk QCB, Fuller JL (1995) Plant invaders. Chapman \& Hall, London

Daehler CC (1998) The taxonomic distribution of invasive angiosperm plants: ecological insights and comparison to agricultural weeds. Biol Conserv 84:167-180

Daehler CC (2005) Upper-montane plant invasions in the Hawaiian Islands: patterns and opportunities. Perspect Plant Ecol Evol Syst 7:203-216

Deutschewitz K, Lausch K et al (2003) Native and alien plant species richness in relation to spatial heterogeneity on a regional scale in Germany. Glob Ecol Biogeogr 12:299-311

Ding JQ, Wang R (1998) Invasive alien species and their impact on biodiversity in China. In: Compilation Group of China's Biodiversity (ed) China's biodiversity: a country study. China Environmental Science Press, Beijing, pp 58-63

Ding JQ, Xie Y (1996) The mechanism of biological invasion and the management strategy. In: Schei PJ, Sung W, Yan X (eds) Conserving China's biodiversity. China Environmental Science Press, Beijing, pp 125-156 
Du WB, Ye YZ, Zhang XY, Yuan ZL (2002) Studies on the harmful nonindigenous plants in Henan, China. Henan Sci 20:52-55

Enomoto T (1999) Naturalized weeds from foreign countries into Japan. In: Yano E, Matsuo M, Shiyomi M, Andow DA (eds) Biological invasions of ecosystem by pests and beneficial organisms. National Institute of Agro-Enviromental Science, Tsukuba, pp 1-14

Flora of China (2007) URL: http://hua.huh.harvard.edu/china/ Forman RTT, Alexander LE (1998) Roads and their major ecological effects. Annu Rev Ecol Syst 29:207-231

Groves RH, Panetta FD, Virtue JG (2001) Weed risk assessment. CSIRO Publishing, Collingwood

Guo SL (1995) Studies on the origin, spread and bioecological characteristics of exotic weeds. Guihaia 15:89-95

Guo Q (2002) Perspectives on trans-Pacific biological invasions. Acta Phytoecol Sin 26:724-730

Guo SL, Li YH (1995) Alien weeds in the southeast of China. Weed Sci (China) 2:4-8

Hou HY (1983) Vegetation of China with reference to its geographical distribution. Ann Mo Bot Gard 70:509-548

Hsu PS (1999) Flora of Shanghai. Shanghai Science and Technology Press, Shanghai

Jenkins PT, Mooney HA (2006) The United States, China, and invasive species: present status and future prospects. Biol Invasions 8:1589-1593

Jin L, Gu Y, Xiao M, Chen JK, Li B (2004) The history of Solidago canadensis invasion and the development of its mycorrhizal associations in newly-reclaimed land. Funct Plant Biol 31:979-986

Khuroo AA, Rashid I, Reshi Z, Dar GH, Wafai BA (2007) The alien flora of Kashmir Himalaya. Biol Invasions 9: 269-292

Koh KS, Na JG, Suh MH, Kil JH, Ku YB, Yoon JH, Oh HK (2000) The effects of alien plants on ecosystem and their management. The Plant Taxonomic Society of Korea, Korea

Lavery PB, Mead DJ (1998) Pinus radiata: a narrow endemic from North America takes on the world. In: Richardson DM (eds) Ecology and biogeography of Pinus. Cambridge University Press, Cambridge, pp 432-449

Lester PJ, Mitchell SF, Scott D (1994). Effects of riparian willow trees (Salix fragilis) on macroinvertebrate densities in two small central Otago, New Zealand, streams. N Z J Mar Freshwater Res 28:267-276

Levine JM, D'Antonio CM (2003) Forecasting biological invasions with increasing international trade. Conserv Biol 17:322-326

Li Y (1998) China weeds. Agriculture Press, Beijing, p 1617

Li B, Chen JK (2002) Ecology of biological invasions: achievements and challenges. World Sci-Tech Res Dev 24:26-36

Li ZY, Xie Y (2002) Invasive alien species in China. China Forestry Publishing House, Beijing

Li B, Hsu PS, Chen JK (2001) Perspectives on general trends of plant invasions with special reference to alien weed flora of Shanghai. Chin Biodivers Sci 9:446-457

Liu QR, Ming Y, Yun-Long Z (2002) A preliminary study on the invasive plants in Beijing. J Beijing Normal Univ (Nat Sci) 38:399-404
Liu J, Ouyang Z, Pimm SL, Raven PH, Wang X, Miao H, Han $N$ (2003) Protecting China's biodiversity. Science 300:1240-1241

Liu J, Liang S, Liu F, Wang R, Dong M (2005) Invasive alien plant species in China: regional distribution patterns. Divers Distrib 11:341-347

Liu J, Dong M, Miao SL, Li ZY, Song MH, Wang RQ (2006) Invasive alien plants in China: role of clonality and geographical origin. Biol Invasions 8:1461-1470

Lonsdale M (1999) Global patterns of plant invasions and the concept of invasibility. Ecology 80:1522-1536

López-Pujol J, Zhang FM, Ge S (2006) Plant biodiversity in China: richly varied, endangered, and in need of conservation. Biodivers Conserv 15:3983-4026

Lu SG, Xu CD, Dong XD, Duan YQ, Wang Y (2006) The impacts of the invasive alien plants on biodiversity in longitudinal range-gorge region of Southwest China. Acta Bot Yunnan 28:607-614

Lu JZ, Weng ES, Wu XW, Weber E, Zhao B, Li B (2007) Potential distribution of Solidago canadensis in China. Acta Phytotaxon Sin 45:670-674

Mack RN, Erneberg M (2002) The United States naturalized flora: largely the product of deliberate introductions. Ann Mo Bot Gard 89:176-189

McGarigal K (2000) Multivariate statistics for wildlife and ecology research. Springer, New York

McNeely JA, Mooney HA, Neville LE, Schei P, Waage JK (2001) A global strategy on invasive alien species. IUCN Gland, Switzerland, and Cambridge, UK, in collaboration with the Global Invasive Species Programme

Mooney HA, Hobbs RJ (eds) (2000) Invasive species in a changing world. Island Press, Washington

Negi PS, Hajra PK (2007) Alien flora of Doon Valley, Northwest Himalaya. Curr Sci 92:968-978

Normile D (2004) Invasive species: expanding trade with China creates ecological backlash. Science 306:968-969

Pan HJ, Tian JY (2001) Harmful nonindigenous plants in Shandong, China. Plant Quarant 15:245-246

Peng CI, Yang KC (1998) Unwelcome naturalization of Chromolaena odorata (Asteraceae) in Taiwan. Taiwania 43:289-294

Pérez FL (1998) Human impact on the high Paramo landscape of the Venezuelan Andes. In: Zimmerer KS, Young KR (eds) New lessons from Nature's geography: biogeographical landscapes and conservation in developing countries. University of Wisconsin Press, Madison, pp 147-183

Pimentel D (2002) Biological invasions: economic and environmental costs of alien plant, animal, and microbe species. CRC Press, Boca Raton

Pyšek P (1998) Is there a taxonomic pattern to plant invasions? Oikos 82:282-294

Pyšek P, Richardson DM (2006) The biogeography of naturalization in alien plants. J Biogeogr 33:2040-2050

Pyšek P, Richardson DM, Rejmánek M, Webster GL, Williamson M, Kirschner J (2004) Alien plants in checklists and floras: towards better communication between taxonomists and ecologists. Taxon 53:131-143

Qiang S (1998) The history, status and prospect of the study on crofton weed (Eupatorium adenophorum Spreng.), a worst worldwide weed. J Wuhan Bot Res 16:354-360 
Qiang S (2005) A review of species, source and invasion of exotic weeds in China. In: Proceedings of the 20th AsianPacific weed science society conference, Ho Chi Minh City, pp 143-150

Qiang S, Cao X (2000) Survey and analysis of exotic weeds in China. J Plant Resour Environ 9:34-38

Reichard SH, White PS (2001) Horticulture as a pathway of invasive plant introductions in the United States. BioScience 51:103-113

Rejmánek M (2000) Invasive plants: approaches and predictions. Austral Ecol 25:497-506

Rejmánek M, Randall JM (1994) Invasive alien plants in California: 1993 summary and comparison with other areas in North America. Madroño 41:161-177

Ren DR (2000) Atlas of China. China Cartographic Publishing House, Beijing

Richardson DM, Brown PJ (1986) Invasion of mesic mountain fynbos by Pinus radiata. S Afr J Bot 52:529-536

Richardson DM, Rejmánek M (2004) Conifers as invasive aliens: a global survey and predictive framework. Divers Distrib 10:321-331

Rozefelds ACF, Cave L, Morris DI, Buchanan AM (1999) The weed invasion in Tasmania since 1970. Aust J Bot 47: 23-48

Sax DF (2002) Native and naturalized plant diversity are positively correlated in scrub communities of California and Chile. Divers Distrib 8:193-210

Silva L, Smith CW (2004) A characterization of the nonindigenous flora of the Azores Archipelago. Biol Invasions 6:193-204

Stadler J, Trefflich A, Klotz S, Brandl R (2000) Exotic plant species invade diversity hot-spots: alien flora of northwestern Kenya. Ecography 23:169-176

Stohlgren TJ, Binkley D, Chong GW, Kalkhan MA, Schell LD, Bull KA, Otsuki Y (1999) Exotic plant species invade hot spots of native plant diversity. Ecol Monogr 69:25-46

Stohlgren TJ, Jarnevich C, Chong GW, Evangelista PH (2006) Scale and plant invasions: a theory of biotic acceptance. Preslia 87:405-426

Tian JY (2004) Shandong invasive alien species and their control methods. Technology Publisher, Beijing

USDA (2007) Germplasm Resources Information Network (GRIN). US Department of Agriculture. URL: http://www.ars-grin.gov

Vitousek PM, D’Antonio CM, Loope LL, Rejmánek M, Westbrooks R (1997) Introduecd species: a significant component of human-caused global change. N Z J Ecol 21:1-16

Wang S, Yan X, Mittermeier RA (1997) China. In: Russell A et al (eds) Megadiversity - earth's biologically wealthiest nations. CEMEX, South Africa, pp 257-281

Weber E (1997) The alien flora of Europe: a taxonomic and biogeographic review. J Veg Sci 8:565-572
Weber E (1998) The dynamics of plant invasions: a case study of three exotic goldenrod species (Solidago L.) in Europe. J Biogeogr 25:147-154

Weber E (2003) Invasive plant species of the world: a reference guide to environmental weeds. CABI Publishing, Wallingford

Weber E, Li B (in press) Plant invasions in China: what is to be expected in the wake of economic development? Bioscience

Wiersema JH (1999) World economic plants: a standard reference. CRC Press, Boca Raton

Wu K (1993) Initial talk about ecosystemic balance of Dianchi Lake waters. Commun Coord Net Domest Lake 1:47-49

Wu SH, Hsieh CF, Rejmánek M (2004a) Catalogue of the naturalized flora of Taiwan. Taiwania 49:16-31

Wu SH, Hsieh CF, Chaw SM, Rejmánek M (2004b) Plant invasions in Taiwan: insights from the flora of casual and naturalized alien species. Divers Distrib 10:349-362

Xiang YC, Peng SL, Zhou HC, Cai XA (2002) The impacts of non-native species on biodiversity and its control. Guihaia 22:425-432

Xie Y, Li ZY, Gregg WP, Li DM (2001) Invasive species in China-an overview. Biodivers Conserv 10:1317-1341

Xu HG, Wang JM, Qiang S, Wang CY (2004) Alien species invasion biosafety genetic resources. Technology Publisher, Beijing

Xu CD, Dong XD, Lu SG (2006a) Invasive plants in Honghe River Basin of Yunnan Province, China. Shengtaixue Zazhi 25:194-200

Xu HG, Qiang S, Han ZM, Guo JY, Huang ZG, Sun HY, He SP, Ding H, Wu H, Wan FH (2006b) The status and causes of alien species invasion in China. Biodivers Conserv 15:2893-2904

Yan H, Bi H, Li R, Eldridge R, Wu Z, Li S, Simpson J (2006) Assessing climatic suitability of Pinus radiata (D. Don) for summer rainfall environment of southwest China. For Ecol Manage 234:199-208

Zerbe S, Choi IK, Kowarik I (2004) Characteristics and habitats of non-native plant species in the city of Chonju, southern Korea. Ecol Res 19:91-98

Zhang SM, Han QZ (1997) Preliminary study on the alien plants in Dalian. J Liaoning Normal Univ (Nat Sci) 20:323-330

Zhang X, Zhong Y, Chen J (2003) Fanwort in eastern China: an invasive aquatic plant and potential ecological consequences. Ambio 32:158-159

Zhong X, Huang Z, Si H, Zan Q (2004) Analysis of ecologicaleconomic loss caused by weed Mikania micrantha on Neilingding Island, Shenzhen, China. J Trop Subtrop Bot 12:167-170

Zhong C, Bai J, Zhang Y (2005) Introduction and conservation of Casuarina trees in China. For Res 18:345-350 